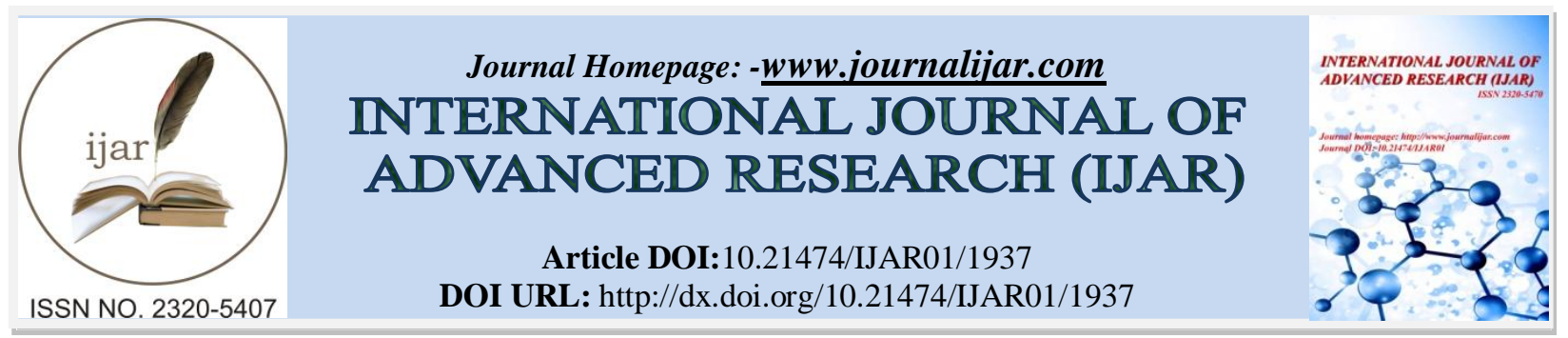

RESEARCH ARTICLE

\title{
CRITICAL SUCCESS FACTORS FOR INTERNATIONAL COMPETITIVENESS INDEVELOPING COUNTRIESTHROUGH MARKETING: LESSONS FOR OMAN
}

Mahmood Sakhi Albalushi ${ }^{1}$, Mansoor Mahfoodh Mubarak Al Qasmi ${ }^{2}$ and Faustino Taderera ${ }^{2}$.

1. CEO, Al Madina Logistic Services Company (SAOC), P.O. Box 1466, P.C. 133, Muscat, Sultanate of Oman.

2. Faculty, Middle East College, Department of Management Studies, Middle East College, Knowledge Oasis Muscat, P.O. Box 79, Al Rusayl, P.C.: 124, Muscat, Sultanate of Oman.

\section{Manuscript Info}

Manuscript History

Received: 12 August 2016

Final Accepted: 22 September 2016

Published: October 2016

\section{Key words:-}

Gross Domestic Product-GDP; Foreign

Direct Investment - FDI; Research and

Development - R \& D; New Product

Development - NPD; Marketing

Orientation - MO; No Objections

Certificates - NOCs.

\section{Abstract}

The main thrust of this research will be to strategically analyse national development planning, competitiveness and marketing best practice scenarios of the United States of America, Germany, South Africa and Oman and see how they have designed national development plans, created international competitiveness and achieved marketing excellence for their countries. The aim is to establish reasons for success and what Oman can learn from these three countries to fine tune its national development plans and marketing practices. The same countries can also learn from Oman its success stories like good international relations, peaceful co-existence, good national image and admirable quality of life. The analysis will also cover the strengths and weaknesses of each system, the positives and negatives, cultural dynamics and the effect on international competitiveness. The Case Study Method was used where themes were formed and analysed using the metrics:- GDP, FDI, Per Capita and Population. Other factors also considered include Institutions, corruption, employment rates, poverty rates, ease of doing business, national competitiveness and infrastructure.Major findings were that closed economies get nowhere, development must cascade all institutions and systems, national image must be built, the national education system must be benchmarked to global best practice and be revised regularly, a good health system is an asset, marketing education at the highest level needed to be developed as well as marketing professional bodies and marketing is the key to unlock national potential both locally and globally and maximize market share and global outreach.Findings also revealed the need for Oman to do away with restrictions in expatriate labour movements (NOCs) and to embrace GCC and global best practice in this area to promote FDI and economic growth. The quality of some Oman graduates was discovered to be below industry expectations and more needed to be done to improve graduate compliance with labour market/industry requirements (a minority though, majority are excellent).

Copy Right, IJAR, 2016,. All rights reserved. 


\section{Introduction:-}

The main thrust of this research will be to strategically analyse national development planning, competitiveness and marketingbest practice scenarios of the United States of America, Germany, South Africa and Oman and see how they have designed national development plans, created international competitiveness and achieved marketing excellence for their countries. The aim is to establish reasons for success and what Oman can learn from these three countries to fine tune its national development plans and marketing practices. The same countries can also learn from Oman its success stories like good political leadership, low national debt, good international relations, being the most friendly country in the Middle East, peaceful co-existence, good national image and admirable quality of life. The analysis will also cover the strengths and weaknesses of each system, the positives and negatives, cultural dynamics and the effect on international competitiveness. Wolfgang, S. (2010) said for a learning innovative and cooperative continent, the future will always be bright. Oman must learn, learn and learn from other countries.

Crow, R. T. (2010) said adherence to the principles that made the USA the world's largest economy is the surest path to continued economic growth and stability over the long run.He said of particular importance were policies that allowed flexibility in labour markets; free movement of capital and labour, unimpeded by excessive regulation; tax rates that minimize disincentives for the development of human and physical capital; and liberalization of international flows of goods, services, people and capital. Oman will need the same strategies for exceptional growth in their business, exports and investment just like any country aspiring to excel on the globalization front. Who can dispute this well documented USA record of success and prosperity and an envy of the whole world? Oman beams on the Strait of Hormuz to service the world.

The main issues would be the following pillars of national development planning:- culture, national image/branding, governance, supply chain, GDP, FDI, infrastructure, e-government, education, innovation and R \& D, unity of purpose, attitude and work ethic, TQM, efficiencies/costs of production, goods and labour markets, corruption, international relations, monetary policies, fiscal policies, freedoms and human rights, property rights, policing and related issues. For Oman issues refer to Appendices 1, 2, 3 and 4 throughout discussions in this research paper.Other issues to be investigated would be:- market gaps, strategic fit, technology, trade agreements, production, HRM development, localization of skills, language challenges, synergies, competitors and international business culture.

How is easy of doing business in Oman versus countries like UAE? Starting a business in Oman takes anything from one to six months to finish all the processes while it takes seven days in the United Arab Emirates. Is this not food for thought in Oman policy imperatives? The world's biggest Shopping Centre is in Dubai, the world's biggest Theme Park is now in Dubai, the tallest building in the world is in Dubai, the largest airline company in the world is Emirates Airlines, one of the biggest airports is in Dubai and the logistics cargo centre of the Middle East is Dubai. The best national image in the Middle East is United Arab Emirates (UAE) too, the envy of the world. Many lessons can be learned from the UAE. There is complete openness, ease of doing business and the best quality of life in the Middle East.

\section{Research Objectives:-}

The purpose and objectives of this research are:-

a. To uncover reasons for national success, failure, good national image;

b. Challenges so that developing countries can draw useful lessons in drawing national development plans and trying to achieve international competitiveness as developmental tools;

c. Uncover marketing value drivers and Marketing Orientation (MO) critical success factors;

d. Value of synergies, support industries, Research and Development institutions as support institutions for national prosperity and marketing excellence;

e. To explore the value of lobby and advocacy and industry associations in unlocking marketing value and promoting (MO) and marketing best practices; finally

f. To unearth what Oman needs to do to achieve global best practice in national development and marketing excellence.

\section{Justification for choosing this topic and the countries chosen:-}

The countries chosen are the USA, Germany, South Africa and Oman which all have a history of fairly good development plans that have propelled those countries to make well documented progress, improvements in 
education, health, industrialization and global visibility and competitiveness which is beyond doubt. Statistics for each country can confirm this and wesummarise them on the table below indicating their GDP statistics. The USA and Germany the developed world while South Africa and Oman represent developing countries. Regional representation is well balanced too as all world regions are represented here (America, Asia, Middle East, Africa and Europe). This will assist with balanced analysis on the effect of culture, geography and development status on national development planning and international competitiveness, though not exhaustive. We chose two developing countries and two developed countries in the USA, Asia, Europe, Middle East and Africa to have a diversity of development scenarios, cultures, political and economic dynamics and reasons for success (Oman, South Africa, the United States of America and Germany).

The countries chosen represent a spread of country sizes, continents, cultures, resource profiles, cultures, political systems, history and geographical diversity and so present a very rich diversity and different angles to explore issues fully and from different perspectives. If one looks at these countries one sees world class mature democracies like the USA and Germany while Oman represents a highly progressive monarchist system with a lot of freedom and prosperity for its people, to lastly a middle of the road new democracy, South Africa, which has just emerged from a tainted and brutal past system of apartheid which made it the most unequal country in the world in favour of the white minority population. Such variety will give credibility and credence to our hypothesis, findings, conclusions and recommendations and challenges mainstream society thinking about which system brings about durable prosperity, development and national competitiveness. The Emirates Center for Strategic Studies and Research (2003) said the success of countries in adopting a knowledge-based economy depends on the quality of the education systems and the institutional structures that facilitate the process from learning to application; the reward system has to be correct to attract the best brains. This means that the best markets attract the best brains. Branch(2000) argued that the best export logistics and supply chain strategy is the development of world class customs and immigration systems and adopting e-logistics as well as good infrastructure in terms of roads, railways, airports and seaways, and lastly having highly qualified personnel to service these institutions. Oman has a few teething problems on customs clearance turnaround, slow internet systems and sometimes disruptions, regular water and electricity supply disruptions in Muscat. That affects supply chain and logistics naturally and add costs as well as sacrificing efficiency. Permanent solutions are required long term as these are very sensitive pillars of any economy.

\section{Focus of the study:-}

The focus of our research will be national development planning, international competitiveness and marketing best practice using the case study method of research. This will be applied systematically to each of the following countries using the same measures or models:- the USA, Germany, Oman and South Africa. Our analysis of each country will centre on Porters' Competitive Advantage of Nations Model and the Porters' Five Forces Model supported by other leading models on national development and international competitiveness. This model says a nation's prosperity depends on its competitiveness, which is based on the productivity with which it produces goods and services. It analyses suppliers, buyers, substitutes, new entrants to an industry and competitive rivalry in the industry. A country's Geography, political system, culture, history, sophistication, innovation, work ethics, support industries and clout is looked at in this analysis using mainly Porters' 'The Competitive Advantage of Nations', Porters' Five Forces Model and other competitiveness models. Brooks\& Stone (2010) in their paper on Infrastructure and Trade Facilitation in Asian APEC, conclude that trade facilitation significantly improves export performance, hence the importance of trade facilitation activities by governments and TPOs. They found that trade facilitation creates regional and international markets but TPOs need to be adequately funded, independent with little government interference, with adequate skills in exports and dynamic and must work with other TPOs like WTO and other national and regional bodies and local industry.

Table 1:-

Country statistics:-

\begin{tabular}{|l|c|l|l|c|}
\hline COUNTRY & $\begin{array}{l}\text { GDP 2010 - US\$ } \\
\text { (ESTIMATE) } \\
\text { BILLIONS }\end{array}$ & $\begin{array}{l}\text { PER CAPITA } \\
\text { US\$ } \\
2010\end{array}$ & $\begin{array}{l}\text { POPULATION } \\
\text { MILLIONS } \\
2010\end{array}$ & - \\
\hline Oman & 53,782 & 26,197 & 2,9 & $\begin{array}{l}\text { FDI 2010 World } \\
\text { Bank - BILLIONS }\end{array}$ \\
\hline South Africa & 354,414 & 10,505 & 49,991 & 19,430 \\
\hline $\begin{array}{l}\text { United States of } \\
\text { America }\end{array}$ & $14,624,184$ & 47,123 & 312,637 & 2,080 \\
\hline Germany & $3,305,898$ & 35,930 & 81,758 & $1,057,000$ \\
\hline
\end{tabular}


Table 2:-

Country Factors to be compared (analysis to be done outside columns for space:-

\begin{tabular}{|c|c|c|c|c|c|c|}
\hline $\begin{array}{l}\text { COUNTRY/ } \\
\text { FACTORS }\end{array}$ & $\begin{array}{l}\text { Institutions \& } \\
\text { Infrastructure } \\
\text { (Plus corruption } \\
\text { and governance), } \\
\text { stage of } \\
\text { economic } \\
\text { development }\end{array}$ & $\begin{array}{l}\text { Macroeconomic } \\
\text { stability \& } \\
\text { Financial } \\
\text { Sophistication }\end{array}$ & $\begin{array}{l}\text { Education\& } \\
\text { Culture }\end{array}$ & $\begin{array}{l}\text { Market size, } \\
\text { Market } \\
\text { Efficiency, } \\
\text { Employment } \\
\text { levels (Goods } \\
\text { and labour } \\
\text { markets), } \\
\text { immigration }\end{array}$ & $\begin{array}{l}\text { R \& D, } \\
\text { Innovation \& } \\
\text { Technological } \\
\text { Readiness }\end{array}$ & Health \\
\hline \multicolumn{7}{|l|}{ Oman } \\
\hline \multicolumn{7}{|l|}{$\begin{array}{l}\text { South } \\
\text { Africa }\end{array}$} \\
\hline USA & & & & & & \\
\hline Germany & & & & & & \\
\hline
\end{tabular}

Conceptual and theoretical framework:-

In this research we will explore the research problem using the case study method (multiple case study method) and will have specific variables or models to be used in this research as instruments of analysis across countries. The four chosen countries are the six cases which form the basis of this research and investigation. The variable to be used would be:- Institutions \& Infrastructure (Plus corruption and governance), stage of economic development; Macroeconomic stability \& Financial Sophistication; Education\& Culture; Market size, Market Efficiency, Employment levels (Goods and labour markets), immigration; R \& D, Innovation \& Technological Readiness and finally Health.

\section{Model:-}

A model is used to show and demonstrate the relationships amongst variables in a given system. In this instance the six main variables are:- Institutions \& Infrastructure (Plus corruption and governance), stage of economic development; Macroeconomic stability \& Financial Sophistication; Education \& Culture; Market size, Market Efficiency, Employment levels (Goods and labour markets), immigration; R \& D, Innovation \& Technological Readiness and Health. 
The following model outlines the relationships of the variables used in this research:The Country National Development Planning \&Competitiveness Matrix:-

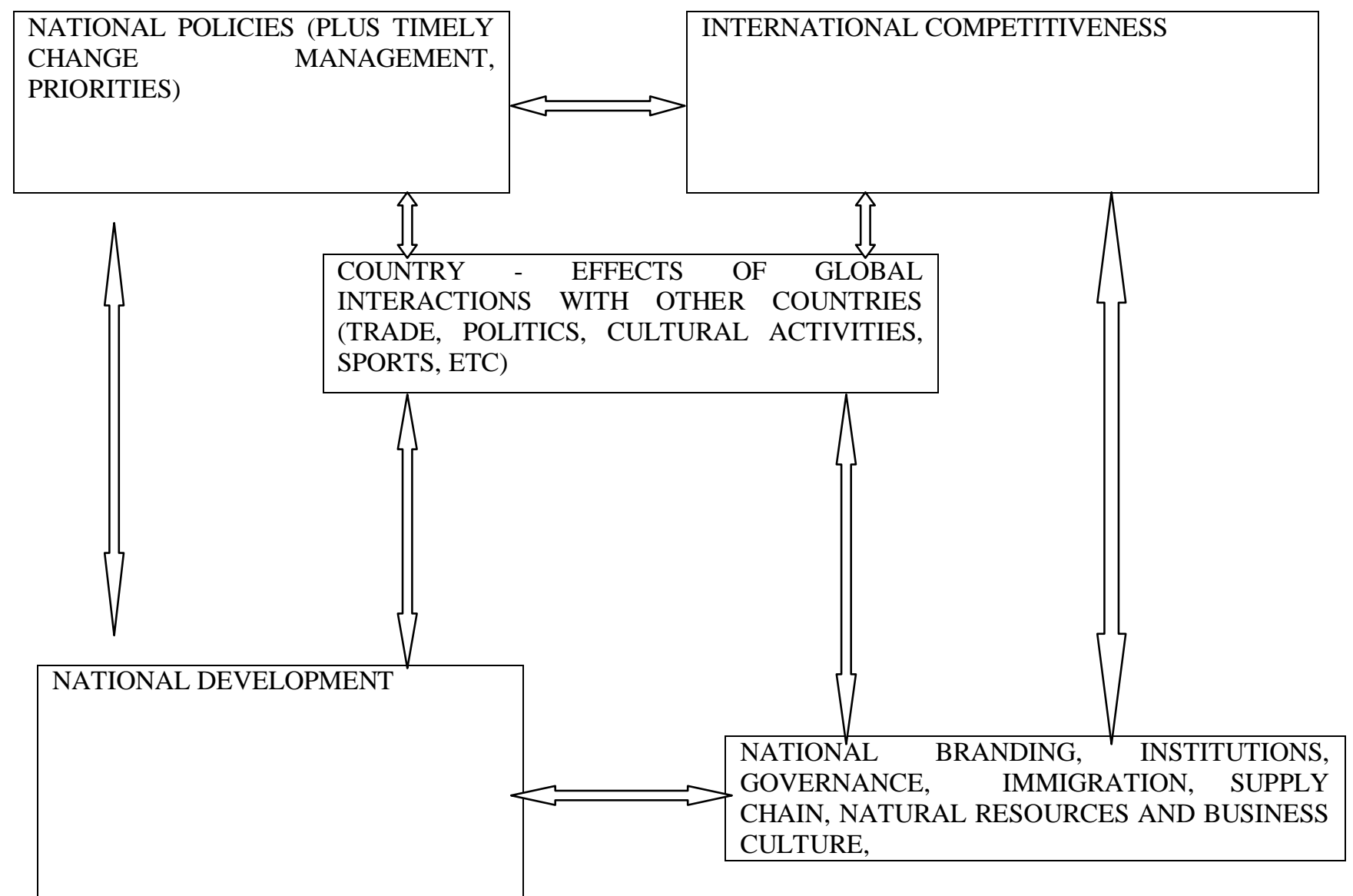

The American dilemma:-

In another interesting development in March 2011 an American panel of eminent economists, business and government strategists was on a CNN television programme debating some of the major reasons why America is now facing cut throat competition from China which is decimating and threatening the existence of American firms. They said the biggest mistake that the USA ever made was to terminate the contracts of 60000 expatriate professors between 1990 and 2010, most of them in the hard sciences and business, as these are the same people who joined mostly Chinese, Indian and other Asian countries' companies/governments and helped develop new breakthrough products and processes which have helped to destroy and decimate American companies up to this day. If they had remained in America their ideas would have been used to develop American companies and curtail transfer of their expertise to these countries. They said it would have been better had they given them American citizenship altogether as a competitive strategy as had been USA strategy since World War 11.

\section{Country analysis and comparisons:-}

The country analysis were extracted from the relevant ministries in these countries as well as World Bank, IMF, WTO and United Nations annual country Reports.

\section{Oman:-}

Introduction:-

The Sultanate of Oman is an Arab state in southwest Asia on the southeast coast of the Arabian Peninsula. It is bordered by the United Arab Emirates (UAE) to the northwest, Saudi Arabia to the west, and Yemen to the southwest. Oman is an absolute monarchy in which the Sultan of Oman exercises ultimate authority but its parliament has many legislative and oversight powers. The Council of Ministers is also very powerful as well as 
Parliamentary Portfolio Committees. Oman is a former British colony and has close ties with the UK and the USA and its citizens enjoy the same level of rights and freedom enjoyed in Western countries, if not better. It is a very rich country.Galagedera, D.U.A.'s research reveals that equity market performance may be positively related to the size of the market and friendliness of the business environment in the form of market size, networks, government regulations, easy of doing business, infrastructure and sophistication of clients as well as positive attitude and work ethic (2010). Research by Parys \& James (2009) discovered that increasing the number of legal guarantees for foreign investors and reducing the complexity of the tax system helps to attract investment and this naturally increases national export performance. Lee \&Baik (2010) concluded that firms that lobby are the ones that get protection, not necessarily the healthy ones, hence it is important to do heavy lobbying to get the government's ear, incentives and protection. Boardman \& Gray (2010) found out that cooperative research centers (CRCs) are key mechanisms for national and subnational governments and private industry for achieving social and economic outcomes with science and technology and this is a major boost for export competitiveness through continuous innovation. Country-of-assembly is shown to affect perceived quality as well as perceived image,Seidenfuss et al(2010). The following factors favour Oman:- free universal education, free universal public health service, a welcoming friendly people to foreigners, peace and tranquility, one of the lowest corruption levels in the world, one of the lowest crime rates in the world, strategic geographical location, lowest tax rates in the world, well established institutions, low cost of production and hard- working dependable and ethical people.

\section{Institutions \& Infrastructure (Plus corruption and governance), stage of economic development:-}

Oman is an absolute monarch, a developing country pegged at number 28th as least corrupt country, number 57th best in the world in terms of easy of doing business and $50^{\text {th }}$ best in terms of quality of life and $34^{\text {th }}$ in terms of global competitiveness rankings. In November 2010, the United Nations Development Programme (UNDP) listed Oman, from among 135 countries worldwide, as the nation most-improved during the preceding 40 years. According to international indices, Oman is one of the most developed and stable countries in the Arab World.Life expectancy is 77 years. Oman has world class institutions, infrastructure, banks, ports and airports and uses five year development plans since 1980 but revision of SME regulations and practices is required.Change in/inadequate government regulations' are at the bottom level of the hierarchy implying highest driving power and require higher attention and focused mitigation strategies. Risks like lack of traceability, transport delays/breakdowns and temperature abuse, cross-contamination in transport and storage have medium driver and dependence powers, Srivastava, Chaudhuri\&Srivastava (2015). The highlighted problems are quite common in business life in Oman and need correction.

\section{Macroeconomic stability \& Financial Sophistication:-}

Oman growth rate for this year has been reduced from 5.2\% to $4.5 \%$. Oman inflation is pegged at 3.5\% while interest rates are pegged at $8 \%$. Oman has got fifteen banks, some private, some public and some jointly owned by government and the private sector. The banking industry has localization of skills of $98 \%$. The economic is solid and institutions strong. But improvements would always be needed.

\section{Education:-}

The literacy rate in Oman in 2010 was $81.4 \%$. Today there are over 1000 state schools and about 650,000 students. Oman has got 50 colleges and universities. Fewgraduates from secondary schools cannot get places in colleges and universities because of low passes, expensive private colleges/universities and only one government university. The gap between graduate skills portfolio and industry requirements is a major weakness of Oman, (see Appendix 1). Many factors explain this, including quality of students recruited into colleges and universities, English language limitations on students when English is the medium of instruction and high labour turnover in the country. There is also a very positive pro-foreigner sentiment throughout country which has the effect of attracting expatriates and investors who can see that they are wanted. Oman is the most expatriate friendly country in the GCC. Research support is good but needs to increase to get more research output. One of the missing links in the Oman education system is the absence of commerce/business subjects at high school at most schools, especially government schools, (subjects like Commerce, Economics, Accounting and Business Studies). These are the seeds for sustainable entrepreneurship and the students normally run successful SMEs themselves, even if they do not proceed to college or university. Societies and communities also use them as business advisers to families, SMEs and the rest of society with an excellent multiplier effect. Their business knowledge creates a business culture in society. Oman must move with speed to correct this anomaly for national benefit. Students with business background are rarely a social welfare case for the government.Human capital accumulation strongly amplifies productivity in differences across countries. 


\section{Market size, market efficiency and employment (goods and labour markets), immigration:-}

The GDP of Oman as of 2010 was US $\$ 53$ billion, exports was US\$36 billion. Per capita GDP was US\$18 000 and FDI was US\$2,05 billion. The market is generally efficient due to well-developed infrastructure, e-logistics and online buying and selling, modern ports/airports and a perfect mixed economy based on modern capitalism. Unemployment is pegged at 10\%. A number of GCC countries, including Oman, have initiated policies to replace foreign workers with nationals by establishing limits on hiring expatriate workers, setting minimum quotas for hiring nationals, and raising the cost of employment of non-nationals. The programme is called Omanisation and has been very successful and rated the best and most successful in the GCC. Oman has good trading relations with the world. If a country does not liberalize its labour market at the outset of its trade reform, the inter-sectoral reallocation of workers will be 30\% slower, and as much as 30\% of the gains in real output and labour productivity in the years following the trade reform will be lost,Kambourov(2009). From a policy standpoint, the message is that while trade reforms are desirable, they need to be complemented by labour market reforms in order to be fully successful. Regulations and restrictions on issues like (No Objections Certificates (NOCs)on expatriates and labour migration and movement need to be reformed and changed to march the freedom in UAE, Qatar and Saudi Arabia. NOCs are not good for free movement of labour and must only apply to labourers and semi-skilled employees not professionals.

\section{R \& D, Innovation \& Technological Readiness:-}

Oman is ranked number fifty five on the Global Innovation Index of the Boston Consulting Group of the USA. Most research conducted in Oman has been done at the behest of the government; agriculture, minerals, water resources, and marine sciences have drawn the most attention. Sultan Qaboos University, founded in 1985, has colleges of science, medicine, engineering and agriculture. Now there is the Oman Research Council whose mandate is to promote research. Getting information from companies is not that easy when doing research, with a few exceptions. A culture of secrecy makes it difficult to get information from companies. Research prizes for researchers are an issue; they are still quite low as an incentive to do research when global comparisons are done.

\section{Health:-}

Oman has got 47 hospitals both public and private which are well equipped with state of the art technology and other facilities, but shortages may be experienced here and there. The major problem is staffing as Oman is losing critical medical and related staff to neighbouring countries like UAE, Saudi Arabia, Qatar and Kuwait who pay much higher salaries. Oman is very active in sporting, cultural, intellectual, social and scientific spheres. Hospitals are fairly good but there are shortages of specialists like neurosurgeons and others and it is common to see Omanis going overseas for specialized treatment and operations.

\section{Biggest challenges and opportunities facing the nation:-}

The biggest challenges facing Oman are:- low oil prices, low investment, erratic water supply disruptions in Muscat which are becoming quite common, gap between the rich and the poor, high population growth (85\% of population is 35 years and below), unemployment amongst the youth (some of them highly educated), shortage of public universities and colleges, fierce competition from UAE, Qatar, Saudi Arabia, Kuwait and other MENA countries, declining oil reserves, slow economic diversification, concerns about quality of education (see Appendices $1 \& 2$ ), low research output and overreliance on the public service for job creation. Despite all this Oman is a shining star in the GCC as it was awarded by the UN, the most developed country in 40 years award in world history, from a desert to a modern state. The current skills shortage in the world requires careful immigration policies to attract highly skilled labour to drive a modern economy. Mrs Angel Merkel, Germany Chancellor, said she wanted to lure highly qualified foreigners to the country. She said, "Germany has eighty million people with seven million foreign born. We want real specialists. We want to offer much better opportunities. We must be part of the war for talent in the world." This is part of long term Germany development strategy, Savage (2002). Oman and other GCC countries can learn a lot from this progressive Germany human resources strategy.

One of the reasons why Oman is lagging UAE, Saudi Arabia, Qatar and Bahrain is the restrictions on skilled labour movement within the country in the form of No Objections Certificates (NOCs) where expatriates cannot transfer from one employer to the next without NOCs and they have to leave Oman for strictly two years outside before coming back. Their natural destination is other GCC countries without these restrictions and look at the growth figures there - fantastic (food for thought for Oman). If a country does not liberalize its labour market at the outset of its trade reform, the inter-sectoral reallocation of workers will be $30 \%$ slower, and as much as $30 \%$ of the gains in real output and labourproductivity in the years following the trade reform will be lost, Kambourov(2009). National 
economies are driven by skilled labour which no country can afford to lose. The restrictions should only apply to labourers and semi-skilled labour not professionals. No developed country has these kinds of restrictions the world over, even NICs. People leave an employer because of abuse or low pay or overworking or all. The reasons for leaving should be addressed by employers so that they do not lose employees rather than forcing people to stay with organisations who offer less favourable employment terms. Competition reallocates skilled labour amongst industries and firms not restrictions, and strategy number one is competitiveness. Employers in Oman do not need NOCs but better conditions of service to retain skilled labour. Free unhindered labour market competition will punish abusive and underpaying employers in favour of those with better conditions of service. Employers loosing employees to other firms will be forced to revise their conditions of service for the better. Better revised conditions of service will be good for both local citizens and expatriate labour. It also means less labour cases for the Oman Government which can then focus on more strategic issues to grow, diversify and manage the economy. That is good for labour, society, for firms and for government. NOCs should be scrapped as they are harming the national economy rather than helping it. NOCs are producing many unintended negative consequences. Many employers are complaining about this too as it is hurting their firms.

The two year restriction on expatriates who leave Oman is simply damaging the Oman economy and Omani firms. Take the example of companies that retrench now because of the low oil prices. If oil prices surged next year the same companies would be on the job market for expatriates and locals. The Oman LabourLaw law does not allow them to recruit their expatriate ex-employees for immediate production. They have to recruit new employees altogether who do not know neither the culture/sociology of Oman nor the culture and practices of that organization. It has been repeated time and again by different researchers that professional employees need at least one year to settle down and be at peak of productivity. It is very clear that this law hurts Oman firms, compromises efficiency and is detrimental to Oman. The promoters of this law did not look at the major and destructive side effects of this law. That is why some countries engage professors for their opinions and analysis before passing highly contentious laws like this one. This law must be repealed without any delay. All other GCC countries, nor any other country in the world, have ever promulgated such a business unfriendly law. At this stage of its development what Oman does not need is any impediment to productivity, efficiency and image. The NOCs and two year ban should only apply to labourers and semi-skilled labour only who were causing havoc in firms. Skilled labour should have the freedom to change employers just like is the case in UK, rest of Europe, the USA, Australia as well as the leading economies in Asia and Africa. You do not burn a house because there is a rat - you target the rat with a pesticide. The prescription has an overdose effect and has many unintended negative consequences for the Omani economy. NOCs should simply be scrapped on professional expatriate labour and remain in force for labourers and semi-skilled workers. They serve no positive purpose on professional expatriate labour, besides not facilitating the GCC vision which advocates free movement of labour and capital, of which Oman is a signatory.Unimpeded free skilled human capital circulation and flow is the cornerstone of any modern successful economy - all countries should learn from the envied Western world why and how they succeeded. The IMF has spoken very strongly against NOCs in Oman too.

The massive opportunities that Oman can exploit are:- develop knowledge society further, engage in serious diversification to gradually replace the oil industry long term, development of Academic Cities, Logistics Cargo Centres, Medical Cities, Tourism Cities, increasing FDI, improving quality of education, establishment of more technical colleges, Poly Techniques and technical universities to support a powerful hybrid industrialization policy and learn from countries in this research as well as countries like Singapore, Taiwan, Malaysia and United Arab Emirates the reasons for their success story.Technical institutions produce doers rather than theorists and are the necessary seeds for entrepreneurship, innovation and new venture creation. They produce people who do not look to government for jobs but drive the country to become a developed country. The rise of public higher education in the 20th century has closely paralleled the Industrial Revolution, creating a different kind of scientific, technological, and organizational model for leading institutions into the new millennium in science, technology, and engineering, (Martin \&Samels2012). From this narrative it becomes clear that colleges and universities have to do targeted recruitments to recruit top industrial managers, technologists, engineers and designers into their systems as teaching professors to engender a culture of industrial compliance. These will be fused with pure academics to enrich academic debates, practices and embracing of reality. Who knows industrial requirements better than someone who has been in industry surely? A galaxy of pure academics only for any institution is now considered a dangerous liability and a mismatch with industrial expectations. Is this not one of the reasons why Oman industry is complaining about graduate non-compliance with labour market requirements and expectations? Mixed recruitments are the trend in the developed world now. 


\section{South Africa:- \\ Brief history}

South Africa is an African country in Southern Africa and is a parliamentary democracy and also the largest economy in Africa. South Africa also contains the largest communities of European, Asian, and racially mixed ancestry in Africa. At the moment only 5\% of the listing at the Johannesburg Stock Exchange is owned by Africans who are $80 \%$ of the population, while only $10 \%$ of land is owned by blacks while whites own $90 \%$ of the land but are $20 \%$ of the population. Since 2004, the country has had many thousands of popular protests, some violent, making it, according to one academic, the "most protest-rich country in the world". Many of these protests have been organised from the growing shanty towns that surround South African cities.

Institutions \& Infrastructure (Plus corruption and governance), stage of economic development:-

South Africa is rated $54^{\text {th }}$ on global competitiveness ratings and has a mixed economy with high rate of poverty and low GDP per capita. South Africa is a middle-income country with an abundant supply of resources, well-developed financial, legal, communications, energy, and transport sectors, a stock exchange that ranks among the top twenty in the world, and a modern infrastructure. South Africa is ranked 25th in the world in terms of GDP (PPP) as of 2008. South Africa is number 34 in terms of easy of doing business. On corruption it is number 54 and has $88 \%$ on literacy. The murder rate is the highest in the world while violent crime and rape are highest in the world. Inequality, unemployment, crime, HIV/AIDS, the brain drain and rape are South Africa's biggest challenges. About a quarter of the population is unemployed, and lives on less than US $\$ 1.25$ a day. $35.7 \%$ of the population is below the poverty datum line.

\section{Macroeconomic stability \& Financial Sophistication:-}

Public debt is $35.7 \%$ of GDP. National reserves stand at US\$49.287 billion. Interest rate is 5.50\%, GDP growth rate $4.40 \%$, inflation $3.70 \%$, unemployment rate $25 \%$, budget deficit $-6.80 \%$ and exchange rate to US\$ is 6.7 .The economy of South Africa is ranked as a upper-middle income economy by the World Bank, which makes the country one of only four countries in Africa represented in this category, (the others being Botswana, Gabon and Mauritius). Banks and financial institutions are world class with a presence of many international financial institutions like Standard Bank and Barclays Bank. The financial markets are free from exchange controls and taxes are quite low by world standards.

\section{Education and Culture:-}

The literacy rate in South Africa is $88 \%$. But South Africa is still living on expatriate labour, mainly from Zimbabwe due to apartheid policies which deprived blacks of universal access to quality education. The lack of adequate appropriate high grade skills is a major drawback for South Africa caused by apartheid. There are many high quality top universities, colleges and schools in South Africa but universal access to all citizens will take time. The flight of skills is making it even more difficult to stabilize skills supply. Some people are leaving the country to escape its brutal violent crime rate. Funding for education is also affected by the world recession and debt overhang from an expensive racial war of attrition.

South Africa in heavily involved in sports like rugby, cricket, soccer, basketball and many others. The country is a cultural melting pot and embraces many people from the whole of Africa and beyond due to the attraction of its large economy. South Africa ranks poorly when it comes to education; only $15 \%$ of high school graduates go to universities in South Africa. There too few universities in South Africa given its population of 50 million people. Government colleges and universities are always the best to provide $80 \%$ of education in any country as they are affordable, cheap and accessible for the public. The biggest barrier to education anywhere in the world is always cost/price. All countries need more government colleges and universities which are cheaper and affordable.The apartheid system built less colleges and created major negative ripple effects on the national economy.

Market size, Market Efficiency, Employment levels (Goods and labour markets), immigration:In 2009 GDP was US\$277.4 billion, exports were US\$67.93 billion while imports were pegged at US\$70.24 billion. FDI was US\$125.7 billion and external debt was US\$73.84 billion while reserves stood at US\$37.41 billion. South Africa compares well to other emerging markets on affordability and availability of capital, financial marketsophistication, business tax rates and infrastructure, but fares poorly on the cost and availability of labour, education, and the use of technology and innovation. 
Unemployment, poverty, HIV/AIDS, a high crime rate, murder and inequality are the major challenges facing South Africa. Sinha (2007) quoting Anholt notes that marketing is at the heart of what makes rich countries rich and that building national identity means ensuring that its brand-image is the way it promotes and represents and shares its culture.

\section{R \& D, Innovation \& Technological Readiness:-}

South Africa is ranked number thirty five on the Global Innovation Index. Several important scientific and technological developments have originated in South Africa. South Africa has many world class universities and research institutes which have patented some inventions like Wits University, University of Cape Town and University of Johannesburg. But the high brain drain and high crime rate threaten this thrust. Skilled migration to the West is a big threat to South Africa. Professionals and academics are running away from the violent crimes, robberies and murders so common in South Africa.

\section{Health:-}

In South Africa, parallel private and public systems exist. The public system serves the vast majority of the population, but is chronically underfunded and understaffed. The wealthiest $20 \%$ of the population uses the private system and are far better served. Health tourism is very popular attracting tourists from the whole world. HIV and AIDS in South Africa are major health concerns, and around 5.5 million people are thought to be living with the virus in South Africa. The shortage of doctors and nurses and other medical personnel is holding back government plans to avail health to all. Some medical personnel do not want to work in rural areas where there is largely a shortage of electricity, clean water, telephones, internet and other facilities as well as access to major cities. Migration to the West is draining medical staff from hospitals. Crime, working conditions and underfunding are the major reasons for migration. Health is still inaccessible to a majority of South Africans, especially in rural areas.

\section{Threats to South Africa:-}

The major challenges facing South Africa are:- endless public sector strikes, high crime rate, migration, HIV/AIDS, land disputes, glaring income inequality, the brain drain, illegal immigration from the whole of Africa as South Africa is viewed as the land of opportunity, a critical shortage of electricity and corruption. Other major problems are to do with:- the national debt burden, global warming and food shortages, inflation, unequal land distribution, Black Economic Empowerment (BEE) policies which are mainly benefiting the ruling ANC elites, shocking and very high rape cases, shortage of education and health facilities, access to rural areas, water and energy supply and lastly infrastructure development. Inequality, poverty and unemployment are the biggest time bombs for South Africa. Most of the ANC promises have not been realized, while the political elite live like Hollywood Stars and European Super League stars in the midst of grinding poverty and destitution. That is not sustainable in the long run and will explode into civil unrest, which has happened already two times.

\section{United States of America:- \\ Brief history}

The United States of Americais a federalconstitutional republic comprising fifty states and declared independence from Britain in 1776. The USA is a democracy benchmark for the whole world, with multi-party politics dominated by the Republican and Democratic Parties. The country is situated mostly in central North America. It is the world's most ethnically diverse and multicultural nations, the product of large-scale immigration from many countries, with nearly every country represented amongst its citizenry. The U.S. economy is the world's largest national economy. America is named after Italian explorer and cartographer Amerigo Vespucci. About 50,000 convicts were shipped to Britain's American colonies in America. The USA symbolizes democracy, freedom, human rights, judicial independence, rule of law, property rights and the highest levels of transparency and accountability at all levels. In 180 years the United States grew to a huge, integrated, industrialized economy that still makes up over a quarter of the world economy. The main causes of its wealth were a large unified market, a supportive political-legal system, vast areas of highly productive farmlands, vast natural resources (especially timber, coal and oil), a cultural landscape that valued entrepreneurship, giving citizenship to 14 million skilled immigrants and attracting millions of highly skilled immigrants from the whole world (the USA has the highest skilled immigrant population in the world), a commitment to investing in material and human capital, and at times a willingness to exploit labor. America is the most open and competitive economy in the world. United Arab Emirates (UAE) dominates the Middle East and is the jewel and diamond of the region because of its open door policies and welcoming investors, tourists and skilled immigrant labour from the whole world. In fact UAE's Dubai is now competing with London, New York, Tokyo, Berlin and Shanghai/Beijing as a world centre. No country has achieved fame without 
international highly skilled immigrant labour and global investors. Isolation and poor relations with other countries have always been a reason for failure.

It is a pride to be an American wherever you go globally and the USA is the obvious envy of the whole world. America represents global standards in education, research, industry, trade and politics. Even their enemies respect them for excellence. Most of the technology and systems used in the world were invented and created in USA.

\section{Institutions \& Infrastructure (Plus corruption and governance), stage of economic Development:-}

Corruption levels are very low in the USA and the country is number $17^{\text {th }}$ in the world on the corruption index. Infrastructure and institutions are well developed and are the best in the world. The world's most advanced railways, airports, ports, harbours, roads and maritime systems characterize the USA. The world recession of 2008 was caused by corruption by bankers in the sub-prime mortgage market in Wall Street, New York, USA. Since then new regulations have been promulgated to curb abuse. $15.1 \%$ of population was living below the poverty datum line in 2010. The USA is the world's most advanced economy with a digital economy and e-government. The IMF, World Bank, United Nations and most major MNCs, TNCs, NGO and other supranational organizations are headquartered in the USA. The most advanced research institutions are also found in the USA. The world's largest nuclear arsenal is in the USA. The USA feeds the world with its massive farming activities, silos and granaries. It is called the farm of the world. Logistics Clusters are driven by six factors namely:-favourable geography, supporting infrastructure, supportive/efficient government, education/research/innovation, collaboration and value added services (like life sciences companies, advanced manufacturing, clean-tech energy and information technology), Sheffi(2014).

\section{Macroeconomic stability \& Financial Sophistication:-}

Credit rating is now AA after downgrading in 2011 due to large public debt. FDI was $\$ 1.280$ trillion, the largest in the world, interest rate was 3.9\%, GDP growth was 3\%, inflation 3.9\% and public debt was US\$14.972 trillion. The economy of the United States is a mixed economyand has maintained a stable overall GDP growth rate, a moderate unemployment rate, and high levels of research and capital investment. The country remains the world's largest manufacturer, Foreign investments made in the United States total almost \$2.4 trillion, which is more than twice that of any other country. American investments in foreign countries total over $\$ 3.3$ trillion, which is almost twice that of any other country. Measured by value of its listed companies' securities, the New York Stock Exchange is more than three times larger than any other stock exchange in the world. New York City is the financial capital of the world alongside London. The U.S. dollar is the currency most used in international transactions. Almost two-thirds of currency reserves held around the world are held in US dollars. The USA is the economic capital of the world.

\section{Education and Culture:-}

13 or 15 American colleges and universities are ranked among the top 20 in the world. The literacy rate in the USA is $99 \%$. The USA used to have the largest number of $\mathrm{PhD}$ degree holders in the world, although it has been overtaken by China now. There are 4,352 state of the art colleges, universities, and junior colleges in the United States, well equipped. Some $80 \%$ of U.S. college students attend public universities. It is very important for governments to provide most $(80 \%)$ of the schools, colleges and universities rather than private ones as government education is cheap, affordable, well equipped, well-staffed and has low student/teacher ratio which is good for students and teachers, argues the USA Commission on Education Report of 2015. Television viewing is largest in America than anywhere in the world. The USA is the educational benchmark and envy of the world. Educational tourism is a major industry. Research output is highest in the USA.

\section{Market size, Market Efficiency, Employment levels (Goods and labour markets), immigration:-}

The economy of the United States is the world's largest and most sophisticated national economy. The United States is the 2nd largest energy consumer in terms of total use. Its nominal GDP was estimated to be nearly $\$ 14.7$ trillion in 2010, approximately a quarter of nominal global GDP. The U.S is the largest trading nation in the world. Its three largest trading partners as of 2010 are Canada, China and Mexico. As of 2010, the European Union as a whole was the largest trading partner of the U.S., whereas Canada, China, and Mexico were the largest individual trading nations. The USA was number 5 on the easy of doing business index in 2010. Unemployment stood at $9 \%$ in 2010, exports were US\$1.280 trillion, imports US\$1.948 trillion.

The USA has very flexible immigration regulations attracting expertise from the whole world. The brain drain from Europe to the United States means that some 400,000 European science and technology graduates now live in the U.S. Nearly 14 million immigrants came to the United States from 2000 to 2010. Small businesses are the largest 
employer in the country representing 53\% of US workers. A total of $91 \%$ of Americans are employed by the private sector. Government accounts for $8 \%$ of all US workers. Over $99 \%$ of all employing organizations in the US are small businesses. The 30 million small businesses in the USA account for $64 \%$ of net new jobs (jobs created minus jobs lost). About 30\% of the entire world's millionaire population reside in the United States (in 2009). Furthermore, $34 \%$ of the world's billionaires are American (in 2011).Unemployment was 9.0\%.

\section{R \& D, Innovation \& Technological Readiness:-}

The USA is number nine on the Global Innovation Index. The United States has been a world leader in scientific research and technological innovation since the late 19th century. Participating in a new business creation is a common activity among USA workers over the course of their careers. Research output is highest in the USA than anywhere in the world. The secrets for research success and high research output are:- full research funding, low teaching loads, long annual vacations (60 days per year) when researchers can do research undisturbed by teaching classes and other administrative duties, incentives for researchers, and financing journal publication 100\%, conference attendance $100 \%$ and giving contact and sabbatical leave to academics. Research is not possible without these ingredients.

\section{Health:-}

The United States life expectancy of 78.4 years at birth ranks it 50th among 221 nations. Approximately one-third of the adult population is obese and an additional third is overweight. The infant mortality rate of 6.06 per thousand places the United States 176th out of 222 countries, higher than all of Western Europe.The Texas Medical Center in Houston, the world's largest medical center, is in the USA. The U.S. health care system far outspends any other nation's in absolute terms. The World Health Organization ranked the U.S. health care system in 2000 as first in responsiveness, but 37th in overall performance. Health care coverage in the United States is a combination of public and private efforts, and is not universal as in all other developed countries. Health tourism is a major income earner for the USA. The USA runs the most sophisticated medical institutions and research centres in the world.

\section{Major challenges to USA prosperity and world leadership:-}

There are currently a number of threats to USA economic and political leadership in the world namely:- heavy borrowings and budget deficits of US\$17 trillion, high unemployment currently at 9.5\%, inequality, high crime rate and overflowing prisons, the drug problem emanating from Mexico, the high crime rate including violent crime and shootings, Anti-Wall Street demonstrations throughout the country against inequality/corruption/bonuses, Loss of Triple A Rating, a dysfunctional and deadlocked Congress, costly global wars and warmongering, global terrorism, world recession, the emergency of nuclear fanatic states like and lastly the cut throat, ruinous and unwinnable competition mainly from China and other Asian nations which is decimating American world market share. How America manages these challenges will decide its long term fate. Other topical issues are:- high HIV/AIDS rate in some states, illegal immigration, unaffordable welfare state, healthcare, jobs, wages, abortion, drugs, suicide, prostitution, gun related crimes (quite regular and frightening these days with many being killed in one go) and murder, high prisoner population (more than 2 million prisoners - the highest prisoner population in the world) and the widening and yawning gap between the rich and poor. Income inequality has become a top issue in the USA.

\section{Germany:-}

\section{Brief history:-}

Germany is a federal, parliamentary, representative democratic republic with a capitalist mixed economy. The Germany economic miracle after the Second World War was started with the replacement of the Reichsmark with the Deutsche Mark as legal tender, removal of price and exchange controls and a solid monetary policy creating a lasting period of low inflation and rapid industrial growth overseen by the government led by German ChancellorKonrad Adenauer and his minister of economics, Ludwig Erhard, raising West Germany from total wartime devastation to one of the most developed nations in modern Europe and the world. Growth came from replacement of currency, low inflation, massive R \& D budgets and good research prizes for professors and engineers/technologists, low interest rates and serious lowering of taxes as well as migration mainly from East Germany. Contrary to popular belief, the Marshall Plan, which was extended to also include Western Germany after it was realized that the suppression of the Western German economy was holding back the recovery of the rest of Europe, was not the main force behind the Wirtschaftswunder. Apart from these factors, hard work and long hours at full capacity among the population in the 1950s, 1960s and early 1970s and extra labor supplied by thousands of Gastarbeiter ("guest workers") provided a vital base for the economic upturn. There were other factors like the massive amounts of money spend by 325000 USA soldiers stationed in Germany used on subsistence, 
entertainment, buying cars and other luxury goods. Germany also benefited from global importation of highly skilled labour as a driver of its economy (more than seven million skilled expatriates as of now).

Institutions \& Infrastructure (Plus corruption and governance), stage of economic development:Germany is the leading producer of wind turbines and solar power technology in the world. The largest annual international trade fairs and congresses are held in several German cities such as Hanover, Frankfurt, and Berlin. Of the world's 500 largest stock market listed companies measured by revenue, the Fortune Global 500, 37 are headquartered in Germany e.g. Volkswagen, Allianz, E.ON, Daimler, Siemens, Metro, Deutsche Telekom, Munich Re, BASF, and BMW. Other large German companies include: Robert Bosch, ThyssenKrupp, and MAN (diversified industrials); Bayer and Merck (pharmaceuticals); Adidas and Puma. The InterCityExpress or ICE is the most advanced world service category of the Deutsche Bahn, is third largest in the world, and serves major German cities as well as destinations in neighbouring countries. Germany has major airports, ports, railways, roads and other modern infrastructure. Germany is number sixteen on the World Corruption Index, a good measure by any standards.

\section{Macroeconomic stability \& Financial Sophistication:-}

GDP was $\$ 3.306$ trillion, public debt was $\$ 4.713$ trillion, $78.8 \%$ of GDP (2010 est.). FDI was $\$ 1.057$ trillion (2010). GDP growth was $3.6 \%$ (2010), inflation 1.3\%. Foreign reserves were US $\$ 233.813$ billion. Reunification with East Germany presented many structural challenges to date. Germany is home to major MNCs, stock exchanges and transnational banks and financial institutions. Germany has a social market economy with a highly qualified labour force, a large capital stock, a low level of corruption, and a high level of innovation. It has the largest national economy in Europe, the fourth largest in the world. The service sector contributes approximately $71 \%$ of the total GDP, industry $28 \%$, and agriculture $0.9 \%$. The average national unemployment rate in 2010 was about $7.5 \%$.First estimates indicate a 3.6\% increase in the price-adjusted GDP for 2010, following a 4.7\% drop in 2009.

\section{Education and Culture:-}

The literacy rate in Germany is $99 \%$. However, a growing number of inhabitants are functionally illiterate. Responsibility for educational oversight in Germany lies primarily with the individual federated states. Germany's universities are recognised internationally; in the Academic Ranking of World Universities (ARWU) for 2008, six of the top 100 universities in the world are in Germany, and 18 of the top 200. Nearly all German universities are public institutions, charging tuition fees of $€ 50-500$ per semester for each student.Germany has also changed its attitude towards immigrants; since the mid-1990s, the government and the majority of Germans have begun to acknowledge that controlled immigration should be allowed based on qualification standards. Germany has been named the world's second most valued nation among 50 countries in 2010. A global opinion poll for the BBC revealed that Germany is recognised for having the most positive influence in the world in 2011. Germany does not have large pockets of poverty or great economic disparity, see (http://www.countriesquest.com/europe/germany/people/social_problems.htm). However, there are substantial numbers of homeless people and problems of violence, alcoholism, and drug abuse, theft and burglary in urban areas, drug use, violence and racism.

\section{Market size, Market Efficiency, Employment levels (Goods and labour markets), immigration:-}

Germany is the largest national economy in Europe, the fourth-largest in the world. Since the age of industrialisation, the country has been a driver, innovator, and beneficiary of an ever more globalised economy. Germany is the world's second largest exporter with $\$ 1.120$ trillion and imports $€ 1.020$ trillion. Foreign reserves stand at US\$233.813 billion in 2011. The service sector contributes around 70\% of the total GDP, industry $29.1 \%$, and agriculture $0.9 \%$. Unemployment stands at $5.9 \%$ in 2011. Industry and construction accounted for $29 \%$ of gross domestic product in 2008, and employed $29.7 \%$ of the workforce. Germany excels in the production of automobiles, machinery, electrical equipment and chemicals. German automotive companies enjoy a extremely strong position in the so called premium segment, with a combined world market share of about $90 \%$. It is estimated, that about 1500 German companies occupy a top three position in their respective market segment worldwide. In about two thirds of all industry sectors German companies belong to the top three competitors.

\section{R \& D, Innovation \& Technological Readiness:-}

Germany is number twenty six on the Global Innovation Index. Germany's achievements in sciences have been significant, and research and development efforts form an integral part of the economy. Germany is also one of the leading countries in developing and using green technologies. Germany is the world's fifth largest consumer of 
energy. The government has set the goal of meeting half the country's energy demands from renewable sources by 2050. Germany has a strong research infrastructure, with stable, growing industrial leaders in the automotive, aerospace, chemical, pharmaceutical and energy industries. Germany is the fourth largest R\&D investor in the world, trailing the U.S., China and Japan and spending 55\% more annually on R\&D than South Korea. Germany contributes about a quarter of the EU-27's total Gross Domestic Expenditure on R\&D (GERD) and nearly 20\% of its GDP. Germany and the UK compete for leadership in the number of technical papers published, with Germany having a 7\% advantage. The top R\&D-spending company in the EU is Volkswagen, with nearly $\$ 8$ billion invested in R\&D in 2009. Five of the top $10 \mathrm{R} \& \mathrm{D}$ companies in the EU are German, each having substantial R\&D-tosales ratios [Volkswagen (5.7\%), Siemens (5.6\%), Daimler (5.3\%), Robert Bosch (9.4\%), and Bayer (9.5\%)]. Germany also emphasizes development of clean technologies and generates a respectable $16 \%$ of its electricity supply coming from renewable sources. At $14.6 \mathrm{GWp}$, Germany has the world's largest photovoltaic energy capacity. It also accounts for Europe's largest share of installed wind capacity, at more than $25 \mathrm{GW}$. The German Federal Government expects renewable energies to account for 35\% of Germany's electricity mix by 2020 and $80 \%$ by 2050.

\section{Health:-}

Germany has the world's oldest universal health care system, dating back to Otto von Bismarck's Social legislation in 1883 . Currently the population is covered by a basic health insurance plan provided by statute. According to the World Health Organization, Germany's health care system was $77 \%$ government-funded and $23 \%$ privately funded as of 2005. In 2005, Germany spent $11 \%$ of its GDP on health care. Germany ranked 20th in the world in life expectancy with 77 years for men and 82 years for women, and it had a very low infant mortality rate $(4$ per 1,000 live births). Drunkenness is a major problem in Germany.

\section{Challenges facing Germany:-}

In the early 1990s the great influx of foreigners, especially illegal aliens and asylum-seekers, coincided with the collapse of the East German Communist regime. Unification brought numerous economic and social problems to Germany, including increased taxes, budget deficits, housing shortages, strikes and demonstrations, unemployment, and rising crime rates. The problem of budget deficits, heavy public debt, unemployment, terrorism, anti-capitalist demonstrations, Eurozone debt crises and a possible world recession are issues of serious concern to Germany. Poor GDP growth performance, high unemployment due to a malfunctioning labor market, and an unsustainable social security system (welfare state). Reforms are necessary to overcome these shortcomings. Germany needs, above all, a market renaissance; must throw off the shackles of its unsustainable social welfare economy and its hallmark consensus approach, whereby group-based cooperative decision-making has undermined competition and markets. The country's debt burden, social security system and its labor market, including trade unions have become the biggest enemies and threat to its economic leadership in Europe and the world. The current influx of refugees from Iraq and Syria is a serious threat to Germany and has deeply divided the country.

\section{Discussions-Major lessons from this research:-}

The major lessons to be learnt from this research are that:-

\section{National debt:-}

A heavy debt burden and irresponsible excessive national borrowings are a big danger for national development planning, national competitiveness and marketing excellence. Borrowing to finance capital projects and the productive sector is always a good thing as long as borrowing levels are sustainable.

\section{Ease of doing business and importation of critical skills:-}

Ease of doing business and the 12 pillars of national competitiveness need to be managed carefully as they are central to national competitiveness. The central reason for success for most of the explored case studies was that they engaged in embracing importation of critical skills through long term immigration to build national capacity, bringing about diversity of ideas and learning from the whole world. Countries hostile to immigration have always fared badly versus those that embraced and welcomed skilled migrant labour (USA, Germany, Singapore, Malaysia, UK, China, South Africa and United Arab Emirates are instructive and undeniable scenarios in this regard). Their economic juggernauts were driven by skilled labour immigration policies and investor friendly policies. But visible and continuous skills transfer to locals needed to take place as part of capacity building of locals. 


\section{Quality of life and Government financial mobilization power:-}

Quality of life, low taxes, peace, rule of law and first class education and health institutions help to attract tourists, skilled migrants, investors.

Government has large sums of money to finance mega-educational institutions to meet national requirements which private players may not do. New degree programmes which may not be viable for private players but essential for the national economy can be run at government institutions in the national interest (e.g. degrees in Fuels and Energy, Nano Technology, Biotechnology, Sociology, Anthropology, Public Policy \& Administration, Fisheries and finally Wood Technology). Private institutions help create competition in education and sometimes bring about breath taking innovations which take time to be implemented or adopted in government due to bureaucracy and red tape. They are very useful to national development. Countries need a breed of both public and private educational institutions. This is well established in Oman.

\section{Academics as consultants:-}

One innovation which Oman does need to adopt which is very common in progressive countries is the coopting and engagement of top academics as consultants to assist Parliamentary Portfolio Committees in debating contentious national issues like Trade Policy, Trade Agreements, Export Development, Omanisation and HRM Policy, Diversification and Non-Oil Economy, SMEs and Entrepreneurship Development, Pollution and Environmental Issues, Technology Transfer, Education \& Higher Education Policy, Energy Policy, Food Security and others. That would eliminate many unintended consequences and pitfalls as professors have sophisticated lenses on any issue.

\section{No Objections Certificates (NOCs):-}

One of the reasons why Oman is lagging UAE, Saudi Arabia, Qatar and Bahrain is the restrictions on skilled labour movement within the country in the form of No Objections Certificates (NOCs) where experts cannot transfer from one employer to the next without NOCs and they have to leave Oman for two years before coming back. The restrictions should only apply to labourers and semi-skilled labour surely not professionals. No developed country has these kinds of restrictions the world over, even NICs. The reasons for leaving should be addressed by employers so that they do not lose employees rather than forcing people to stay with organisations who offer less favourable employment terms. Employers in Oman do not need NOCs but better conditions of service to retain skilled labour. NOCs should be scrapped as they are harming the national economy rather than helping it. NOCs are producing many unintended negative consequences. NOCs deal with symptoms rather than address the cause of labour leaving certain employers. Those causes should be addressed by employers at firm level not through NOCs. NOCs should be scrapped as soon as possible as they are doing a serious disservice to the Oman economy by restricting free movement of skilled labour, one of the cornerstones and pillars of any modern economy.Unimpeded free skilled human capital circulation and flow is the cornerstone of any modern successful economy - all countries should learn from the envied Western world why and how they succeeded.

\section{Final observation:-}

It should be noted that there is no political system which can be said to be a panacea for national development planning and international competitiveness as we find different systems delivering good results in different countries. Unskilled labour market flexibility, a labor market institution that reduces legal constraints imposed on residual claimants (managers and owners) to take necessary actions to maintain or enhance profitability, is associated with increases in performance persistence and that financial and labor market institutions, public equity market development (respectively, skilled labour market availability) have a positive (respectively negative) impact for domestic firms only,Chacar, A.S. (2010:1119-1140). He said the spirit of adventure and discovery 500 years ago changed the pace of European development completely; while China, India, the Middle East and the rest of Asia stagnated for some 500 years, Europe's economy frog-leaped, overtook Asia, and increased its GDP seven times from 600 to 4,500 US\$ per capita. That showed clearly that embracing globalization, free unimpeded movement of capital and people can improve GDP, sophistication, quality of life and product choice for any country and Oman and South Africa are no exception.The biggest enemy of economic development is too many restrictions on movement of people and capital. That is the main difference between success and failure amongst countries.

Oman prides itself of having attained so much in so short a time frame but it still has a lot to learn from the developed world and other highly successful states like Japan, Germany, China, South Africa, Singapore, Malaysia, India, Brazil, Switzerland, Qatar, Belgium, UK, USA and United Arab Emirates. It is very useful to know their reasons for success. The same countries can learn a lot from Oman too. Douglas, B. H. (2000) contented that the old 
political battles that have consumed humankind during most of the twentieth century-black versus white, Left versus Right, male versus female - will fade into the background and that the only battle worth fighting and winning, the only one that could set us free, is The People versus The Corporate Cool Machine or corporate brands and national brands.

Corruption is number one enemy of national development, competitiveness and marketing excellence; dealing with corruption head on is good national cleansing that maintains and builds national image, trust and confidence within and outside the country;

\section{Findings:-}

Our findings from this research as well as from literature conclusively confirm the following scenarios:-

- The whole economy needs to be transformed and developed;

- Good national policies drive national development, competitiveness and marketing performance for nations and their corporates;

- Closed economies get nowhere;

- One of the missing links in the Oman education system is the absence of commerce subjects at high school at most schools, especially government schools (subjects like Commerce, Economics, Accounting and Business Studies). These are the seeds for sustainable entrepreneurship and the students normally run successful SMEs themselves, even if they do not proceed to college or university. Societies and communities also use them as business advisers to families, SMEs and the rest of society with an excellent multiplier effect. Their business knowledge creates a business culture in society. Oman must move with speed to correct this anomaly for national benefit. Students with business background are rarely a social welfare case for the government.

- Good international relations and trade agreements facilitate trade and national branding;

- Building national image is not a one day affair but also demands consistently good policies, quality of life, ease of doing business, national competitiveness, predictability and transparent government;

- One of the reasons why Oman is lagging UAE, Saudi Arabia, Qatar and Bahrain is the restrictions on skilled labour movement within the country in the form of No Objections Certificates (NOCs) where experts cannot transfer from one employer to the next without NOCs and they have to leave Oman for two years before coming back. The restrictions should only apply to labourers and semi-skilled labour surely not professionals. No developed country has these kinds of restrictions the world over, even NICs. The reasons for leaving should be addressed by employers so that they do not lose employees rather than forcing people to stay with organisations who offer less favourable employment terms. Employers in Oman do not need NOCs but better conditions of service to retain skilled labour. NOCs and two year restrictions should both be scrapped urgently as they are harming the national economy rather than helping it. NOCs are producing many unintended negative consequences and stifling economic growth, job creation and FDI inflow into Oman at a time the government badly needs all three.

We leave it to other researchers to do further research and dig deeper into other reasons why countries achieve excellent national development planning through marketing excellence. Oman is no doubt a jewel for the world.

\section{References:-}

1. Boardman, C. \& Gray D. (2010). 'The new science and engineering management: cooperative research centers as government policies, industry strategies, and organizations.' The Journal of Technology Transfer, 35(5), 445459.

2. Branch, A. E. (2000). Export practice and management. USA: Cengage Learning.

3. Brooks, D. H. and Stone, S. F. (2010). 'Infrastructure and trade facilitation in Asian APEC.'Asian Development Review, 27(1), 15-17.

4. Chacar, A. S., et al (2010). 'Bringing institutions into performance persistence research: Exploring the impact of product, financial, and labor market institutions.' Journal of International Business Studies, 41(7), 1119-1140.

5. Crow, R.T. (2008). 'Encouraging growth and stability.' Journal of Business Economics. 43(4), 17-24.

6. Douglas, B. H. (2002). 'Why do brands cause trouble?a dialectical theory of consumer culture and branding.' Journal of Consumer Research, 29(1), n.p.

7. Galagedera, D.U.A. (2010). 'Association between environmental factors and equity market performance: evidence from a nonparametric frontier method.' Financial Markets and Portfolio Management, 24(3),245-269. 
8. Kambourov, G. (2009). 'Labour market regulations and the sectoral reallocation of workers: the case of trade reforms.' The Review of Economic Studies, 76(4), 20-25.

9. Lee, S. \&Baik, Y. (2010). 'Corporate lobbying in antidumping cases: looking into the continued dumping and subsidy offset act.' Journal of Business Ethics, 96(3), 467-478.

10. Martin, J \&Samels, J.E. (2012).The rise of the polytechnic university. [Online] Available from: http://www.universitybusiness.com/article/polytech-renaissance. Accessed: 10th May 2015.

11. Parys, S. V. and James S. (2010). 'The effectiveness of tax incentives in attracting investment: panel data evidence from the CFA Franc zone.' International Tax and Public Finance. vol. 17, no. 4, pp. 400-429.

12. Savage, M. (2002). Savage nation.New York: Penguin Group.

13. Seidenfuss K., et al (2010). "Assembly and component origin effects: an ASEAN consumer perspective." Journal of Consumer Marketing, vol. 27, no. 6, pp.488-498.

14. Sinha, R. I. (2007). 'Worlds apart: nation-branding on the national geographic channel.' Media, Culture \& Society. vol. 29, no. 4, pp. 569-592.

15. Sheffi, Y. (2014). Logistics clusters, delivering value and driving growth. Massachusetts: The MIT Press.

16. Srivastava, S.K., Chaudhuri, A. \&Srivastava, R.K. (2015). Propagation of risks and their impact on performance in fresh food retail: The International Journal of Logistics Management, 26(3), 568-602.

17. The Emirates Center for Strategic Studies and Research, (2003).Human resource development in a knowledgebased economy. The Emirates Center for Strategic Studies and Research: Abu Dhabi.

\section{Appendix 1:- Only 47\% of graduates get jobs in Oman}

Source: http://timesofoman.com/article/76950/Oman/Education/More-than-50-per-cent-Omani-graduates-unableto-get-employment

Appendix 2:-Courses in Oman fail to meet job market needs: Shura panel (Parliament of Oman)

Source: http://timesofoman.com/article/78209/Oman/Education/'Courses-at-universities-and-private-colleges-inOman-fail-to-meet-the-requirements-of-the-job-market

Appendix 3:-Omanisation is obstacle to economic growth in Oman

Source: http://timesofoman.com/article/91232/Oman/Omanisation/'Omanisation-is-obstacle-to-economic-growthin-Oman'

Appendix 4:-

WORLD TRADE ORGANISATION TRADE REPORT 2012

OMAN/UNITED ARAB EMIRATES TRADE COMPARISON

OMAN TRADE STATISTICS - IMPORTS, EXPORTS \& GDP

OMAN

BILLIONS OF US\$

\begin{tabular}{|l|l|l|l|}
\hline & EXPORTS & IMPORTS & GDP \\
\hline 2012 & 48.4 & 23.4 & 81.8 \\
\hline
\end{tabular}

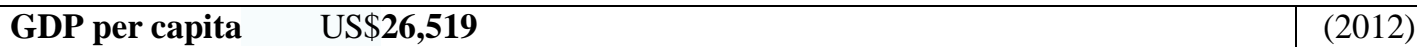

UAE TRADE STATISTICS - IMPORTS, EXPORTS \& GDP

BILLIONS OF US\$

\begin{tabular}{|l|l|l|l|}
\hline & EXPORTS & IMPORTS & GDP \\
\hline 2012 & $\$ 300.6$ & 220.3 & 360 \\
\hline
\end{tabular}

\begin{tabular}{l|l} 
GDP per capita & US\$48,158 (2012)
\end{tabular}

Source: Ministry of Finance, Oman 